\title{
Antimicrobial and Antioxidant Activity of Anacardium occidentale L. Flowers in Comparison to Bark and Leaves Extracts
}

\author{
Rubenice Amaral da Silva', Silvana Amado Liberio', Flavia M. M. do Amaral'1, \\ Flavia Raquel Fernandes do Nascimento', Luce Maria Brandão Torres², \\ Valério Monteiro Neto ${ }^{3,4}$, Rosane Nassar Meireles Guerra ${ }^{{ }^{*}}$ \\ ${ }^{1}$ Laboratory of Immunophysiology, Universidade Federal do Maranhão, Campus do Bacanga, \\ São Luis, Brazil \\ ${ }^{2}$ Instituto Botânico de São Paulo, São Paulo, Brazil \\ ${ }^{3}$ Departament of Pathology, Universidade Federal do Maranhão, \\ São Luis, Brazil \\ ${ }^{4}$ Universidade Ceuma, São Luís, Brazil \\ Email: *rnmguerra@pq.cnpq.br
}

Received 6 January 2016; accepted 25 April 2016; published 28 April 2016

Copyright (C) 2016 by authors and Scientific Research Publishing Inc.

This work is licensed under the Creative Commons Attribution International License (CC BY). http://creativecommons.org/licenses/by/4.0/

(c) (i) Open Access

\section{Abstract}

Anacardium occidentale $\mathrm{L}$., Anacardiaceae, is frequently used to treat infections. We evaluated the antimicrobial and antioxidant activity of extracts obtained from aerial parts of the plant in comparison with the extract prepared with the flowers. Ethanol extracts of the leaves (EEL), stem bark (EEB), and flowers (EEF) were prepared separately. The antimicrobial activity was evaluated by agar diffusion and broth dilution methods. The minimum bactericidal and fungicidal concentrations were determined against: Streptococcus mutans, Lactobacillus acidophilus, Staphylococcus aureus, MRSA, Enterococcus faecalis, Streptococcus pyogenes, Pseudomonas aeruginosa, Proteus mirabilis, Escherichia coli, Klebsiella pneumoniae, Helicobacter pylori, Salmonella choleraesuis, Candida albicans, and Candida tropicalis. The antioxidant activity of the extracts was evaluated based on their scavenger capacity of 2,2-diphenyl-1-picrylhydrazyle. The phytochemical profile was analyzed by colorimetric methods and by HPLC with UV detection. All extracts exhibited antioxidant and antimicrobial activity. Although, the EEF was the most effective since it inhibited the growth of all 14 microorganisms tested. Anacardic and galic acids were identified in all extracts as well phenolic compounds, triterpenes, flavones and xanthones. In conclusion, the extracts obtained from the aerial parts of $A$. occidentale, mainly the extract of flowers that was the most effective, are rich in bioactive metabolites that exert a potent antioxidant and antimicrobial effect. Taken together, the results indicate an important biotechnological potential of $A$. occidentale as a 
source of compounds with broad-spectrum antimicrobial and of antioxidant activity to be used in the food and cosmetics industry.

\author{
Keywords
}

\author{
Anacardium occidentale, Antimicrobial Agents, Flowers, Cashew, Caju, Antioxidant
}

\title{
1. Introduction
}

Anacardium occidentale L. (Anacardiaceae), popularly known as cashew tree, is native from Brazil. The plant is mainly found along the coast of the northeastern states [1] [2] and is of great economic and medicinal value [3]. The main ethnopharmacological applications of the species include the treatment of infectious and inflammatory diseases and pain conditions, such as venereal diseases, skin diseases, diarrhea, stomatitis, aphthae, bronchitis, intestinal cramps, muscle weakness, diabetes, tooth pain, weakness, inflammation, psoriasis, and cough [4]-[9].

Studies have described the antimicrobial activity of different parts of A. occidentale, such as the fruits [3] [10]-[15], stem bark [16]-[25], leaves [16]-[29] and gum [30] [31], but there are no reports of similar activity in the flowers.

The most frequent antimicrobial activity was described to the leaves and barks against bacteria (Staphylococcus aureus, Streptococcus mutans, Streptococcus sobrinus, Escherichia coli, Enterococcus faecalis among others) and fungi (Candida albicans) [32].

Similarly, antioxidant, considering the activity in comparison to quercetin, has been described else whereby fruits, pseudofruis and roots [28] [33]-[38], but not for the flowers.

With respect to the chemical components found in the aerial parts of the cashew tree, phenolic compounds such as anacardic acids, cardanols, cardols and 2-methycardols have been isolated from the cashes nut shell liquid (CNSL) [12] [39]. On the basis of these considerations, we evaluated comparatively the antimicrobial and antioxidant activity of extracts obtained from the flowers, leaves and stem bark of A. occidentale in order to determine which aerial part exhibits higher activity, since most studies have evaluated these components separately.

\section{Materials and Methods}

\subsection{Plant Material}

The flowers, leaves and stem bark of A. occidentale were collected with a cutting instrument at the Campus of the Federal University of Maranhão (Universidade Federal do Maranhão - UFMA), São Luís, Maranhão, Brazil as described previously [40] [41]. The species was identified at the Ático Seabra Herbarium of UFMA and a voucher specimen was deposited (No. 1050/SLS017213).

\subsection{Preparation of the Extracts}

The flowers, leaves and stem bark were separately dried at room temperature $\left(24^{\circ} \mathrm{C} \pm 1^{\circ} \mathrm{C}\right)$ for 24 hours, followed by drying in an oven at $37^{\circ} \mathrm{C}$ for 7 days. The dried material was triturated in an electrical grinder (TENAL TE 340) and extracted by maceration in absolute ethanol P.A. The process was repeated weekly for 3 weeks according to Melo et al. [22], with some modifications. The extracts were concentrated under reduced pressure, lyophilized, and stored in sterile flasks at $4{ }^{\circ} \mathrm{C}$, for the subsequent assays. The mean yield was $15 \%$ for the flower extract (EEF), 13\% for the (EEL), and 18\% for the (EEB). For the in vitro microbiological assays, $20 \mathrm{~g}$ of each lyophilized extract was resuspended in $100 \mathrm{~mL}$ sterile distilled water and sterilized by filtration through a $20-\mu \mathrm{m}$ membrane (Sartorius). For chemical analysis, $10 \mathrm{~g}$ of the lyophilized extracts were resuspended in absolute ethanol P.A. (Merck).

\subsection{Chromatographic Analysis (HPLC/UV) of the Anacardium occidentale Extracts}

The extracts were analyzed by high-performance liquid chromatography with UV detection (HPLC/UV) with an analytical scale. The chromatograms of EEF, EEL and EEB were obtained with the Varian system (Pro Star 310, 
Varian Star Workstation, 6.0) using the following program parameters: elution time of 40 min, detection at 278 $\mathrm{nm}$, and a flow rate of $1 \mathrm{~mL} / \mathrm{min}$. A Polaris C-18 reverse-column, protected by a $2.5-\mathrm{cm}$ pre-column, and a $20-\mu \mathrm{L}$ loop were used. The mobile phase consisted of ultrapure water (Milli-Q) containing $2 \%$ acetic acid (A) or acetonitrile (Merck) (B) as follow: $0 \mathrm{~min}-30 \mathrm{~min}, 70 \% \mathrm{~A}$ and 30\% B until 50\% A and 50\% B. Time of $30 \mathrm{~min}$ $40 \mathrm{~min}, 50 \% \mathrm{~A}$ and $50 \% \mathrm{~B}$ until $30 \% \mathrm{~A}$ and $70 \% \mathrm{~B}$. The results are expressed as retention time (Rt) in minutes and concentrations are expressed as percentage (\%) based on integration of the peak areas.

\subsection{Evaluation of Antimicrobial Activity}

\subsubsection{Microorganisms}

Antimicrobial activity was determined against reference strains of the following microorganisms:

Gram-positive bacteria: Streptococcus mutans (ATCC 25175), Lactobacillus acidophilus (ATCC 4356), Staphylococcus aureus (ATCC 25923), methicillin-resistant Staphylococcus aureus-MRSA (ATCC 3438402), Enterococcus faecalis (ATCC 29212), and Streptococcus pyogenes (ATCC 19615).

Gram-negative bacteria: Pseudomonas aeruginosa (ATCC 27853), Proteus mirabilis (ATCC7002) Escherichia coli (ATCC 25922), Escherichia coli (ATCC 51446), Klebsiella pneumoniae (ATCC 13883), Klebsiella pneumoniae (ATCC 700503), and Helicobacter pylorim (ATCC 43504). Salmonella choleraesuis was isolated from a case of human infection.

Fungi: Candida albicans (ATCC 18804), Candida albicans No.37, Candida albicans No.12, Candida albicans No. 1, Candida tropicalis No.84, Candida tropicalis No.82, Candida tropicalis No. 59 and Candida tropicalis No.39, isolated from cases of human infection.

The ATCC strains used were obtained from the Oswaldo Cruz Foundation (Fundação Oswaldo Cruz), Rio de Janeiro.

The bacteria were cultured in brain-heart infusion (BHI) broth (Difco) at $37^{\circ} \mathrm{C}$ for 24 hours. The fungal strains were cultivated on Sabouraud-dextrose agar (Difco) and incubated at $37^{\circ} \mathrm{C}$ for 24 hours. The microbial suspensions used for susceptibility testing were prepared in sterile saline $(0.9 \% \mathrm{NaCl})$. Turbidity was adjusted to a 0.5 McFarland standard $\left(10^{8} \mathrm{CFU} / \mathrm{mL}\right)[42]$.

\subsubsection{Agar Diffusion}

Antimicrobial activity was evaluated by the agar diffusion method using the cavity technique for screening [43]. Plates containing BHI agar were used for Streptococcus mutans and Lactobacillus acidophilus, blood agar for Helicobacter pylori, Streptococcus pyogenes and Enterococcus faecalis, Mueller-Hinton agar for the other bacteria, and Sabouraud-dextrose agar for Candida albicans and Candida tropicalis. Perforations (wells) measuring $5 \mathrm{~mm}$ in diameter were made in the agar media. The wells were then filled with the standard microbial suspensions using a sterile swab and with $25 \mu \mathrm{L}$ of the extracts (EEF, EEB, and EEL) and control solutions. Absolute ethanol was used as solvent control, $0.12 \%$ chlorhexidine gluconate was used as positive control for bacteria, fluconazole (128 $\mu \mathrm{g} / \mathrm{mL})$ as positive control for fungi, and distilled water as negative control in all assays.

The plates were incubated at $37^{\circ} \mathrm{C}$, for 1 hour, for diffusion of the extracts and control solutions and then inverted for incubation. The BHI and blood agar plates were incubated under microaerophilic conditions in a $5 \%$ $\mathrm{CO}_{2}$ atmosphere at $37^{\circ} \mathrm{C}$, for 48 hours. The blood agar plates with the Helicobacter pylori were incubated under microaerophilic conditions in a $5 \% \mathrm{CO}_{2}$ atmosphere, at $37^{\circ} \mathrm{C}$, for 72 hours. The Sabouraud and Mueller-Hinton agar plates were incubated under aerobic conditions for 24 hours. All assays were carried out in duplicate for each microorganism. After incubation, the inhibition halos were measured in millimeter.

\subsubsection{Determination of Minimum Bactericidal and Fungicidal Concentrations}

The minimum bactericidal concentration (MBC) and minimum fungicidal concentration (MFC) were determined by the broth dilution method [43], using serial dilutions of EEF, EEL and EEB in BHI broth at concentrations ranging from 0.31 to $2 \mathrm{mg} / \mathrm{mL}$. Each tube was inoculated with $1 \mu \mathrm{L}$ of the microbial suspension $\left(10^{8}\right.$ $\mathrm{CFU} / \mathrm{mL}$ ) and incubated at $37^{\circ} \mathrm{C}$, for 24 hours. Next, aliquots $(1 \mu \mathrm{L})$ of the tubes were streaked onto plates containing BHI agar for S. mutans and Lactobacilus acidophilus, blood agar for Helicobacter pylori, Streptococcus pyogenes and Enterococcus faecalis, Mueller-Hinton agar for the other bacteria, and Sabouraud agar for Candida albicans and Candida tropicalis. The MBC and MFC were determined considering the lowest concentrations of the each extract that completely inhibited microbial growth. It was not possible to determine the minimum in- 
hibitory concentration because of the color and turbidity of the extracts.

\subsection{Determination of Antioxidant Activity}

Aliquots ( $5 \mu \mathrm{L}$ ) of each extract (200 $\mu \mathrm{g})$ and of quercetin used as the standard $(1 \mathrm{mg} / \mathrm{mL}$ in methanol) were applied to silica gel $60 \mathrm{~F}_{254}$ chromatography plates $(0.2 \mathrm{~mm}$, Merck). The mobile phase consisted of a mixture of n-butanol, acetic acid and water (67:23:10). The chromatograms were developed using a methanol solution of 0.2\% 2,2-diphenyl-1-picrylhydrazyle (DPPH, Sigma). A purple color was seen within approximately 30 min, and white or yellow spots were indicative of DPPH free radical-scavenging activity [44]. The retention factor (Rf) of the spots was calculated and the chromatograms were photographed and stored in the CAMAG system.

Antioxidant activity was quantified in 96-well plates in an ELISA reader (KC4-Bio-Tek Instruments, Inc., USA). For this purpose, $70 \mu \mathrm{L}$ of a methanol solution of DPPH $(0.3 \mathrm{mM})$ and $180 \mu \mathrm{L}$ of the extract (concentrations of 4, 2, 1 and $0.5 \mu \mathrm{g} / \mathrm{mL}$ ) were added to each well. Quercetin $(4 \mu \mathrm{g} / \mathrm{mL})$ was used as positive control. Analyses were carried out in triplicate. The microplate was kept at room temperature and the intensity of absorbance (515 nm) was measured after 15 and $30 \mathrm{~min}$. Antioxidant activity was calculated as percentage (\%AA) based on the absorbance values as follows: $\mathrm{AA}=\left(\mathrm{Abs}^{\text {sample }}-\mathrm{Abs}^{\text {blank }}\right) \times 100 / \mathrm{Abs}^{\text {control }}[45]$.

The effective concentration $\left(\mathrm{EC}_{50}\right)$ of the extracts was calculated from the dose-response curve of DPPH radical-scavenging activity in relation to quercetin (Merck) after measurement in a spectrophotometer (Shimadzu, Japan) at $512 \mathrm{~nm}(\mathrm{n}=3)$. The $\mathrm{EC}_{50}$ was defined as the concentration of the extract necessary to scavenge $50 \%$ of the initial DPPH concentration, and was also called inhibitory concentration $\left(\mathrm{IC}_{50}\right)$ [45].

\subsection{Statistical Analysis}

The data were processed and analyzed using the Stata 10.0 program (Stata Corporation, College Station, TX, USA).The variables are expressed as mean \pm standard deviation. The Mann-Whitney test was used for comparison between two variables and the Kruskal-Wallis test for multiple comparisons. The level of significance was set at $5 \%(\mathrm{p}<0.05)$.

\section{Results}

\subsection{Chromatographic Profile (HPLC/UV) of the Leaf, Flower and Bark Extracts of Anacardium occidentale}

Figure 1 shows the chromatographic profile of EEF with 37 peaks and their respective retention times $\left(T_{r}\right)$. The chromatographic profile of EEL presented 33 peaks and that of EEB 35 peaks. In all chromatograms, smaller peaks were detected below $4 \%$.

\subsection{Antimicrobial Activity}

The antimicrobial activity of the A. occidentale EEF, EEL and EEB was tested against 14 bacterial species and/or strains using chlorhexidine as standard

As shown in Table 1 EEL exhibited bactericidal activity against 10 microorganisms and EEB against 9, whereas EEF was effective in inhibiting the growth of all 14 bacteria strains tested (Streptococcus mutans, Lactobacillus acidophilus, Staphylococcus aureus, Methicillin-Resistant Staphylococcus aureus-MRSA, Enterococcus faecalis, Streptococcus pyogenes, Pseudomonas aeruginosa, Proteus mirabilis, Escherichia coli (ATCC 25922 and ATCC 51446), Klebsiella pneumoniae (ATCC 13883 and ATCC 700503), Helicobacter pylori and Salmonella choleraesus previously isolated from a human infection).

The antimicrobial efficacy of EEF was also demonstrated by the Minimum Bactericidal Concentration (MBC), since the values found to the flowers were significantly higher than the values found to the leaves and bark extracts as shown in Table 2, since it was not possible to determine the MBC the other extracts EEL and EEB to Klebsiella pneumonia; Lactobacillus acidophilus, Pseudomonas aeruginosa, Streptococcus mutans, Streptococcus pyogenes.

EEF exhibited antimicrobial activity against the different Candida albicans and Candida tropicalis strains as demonstrated by the inhibition halos (Table 3) or the determination of MFC. In contrast EEL and EEB are unable to form inhibition halo to all Candida tropicalis samples and to the majority of tested samples of Candida albicans, being effective only to the strain 37 (Table 4). 

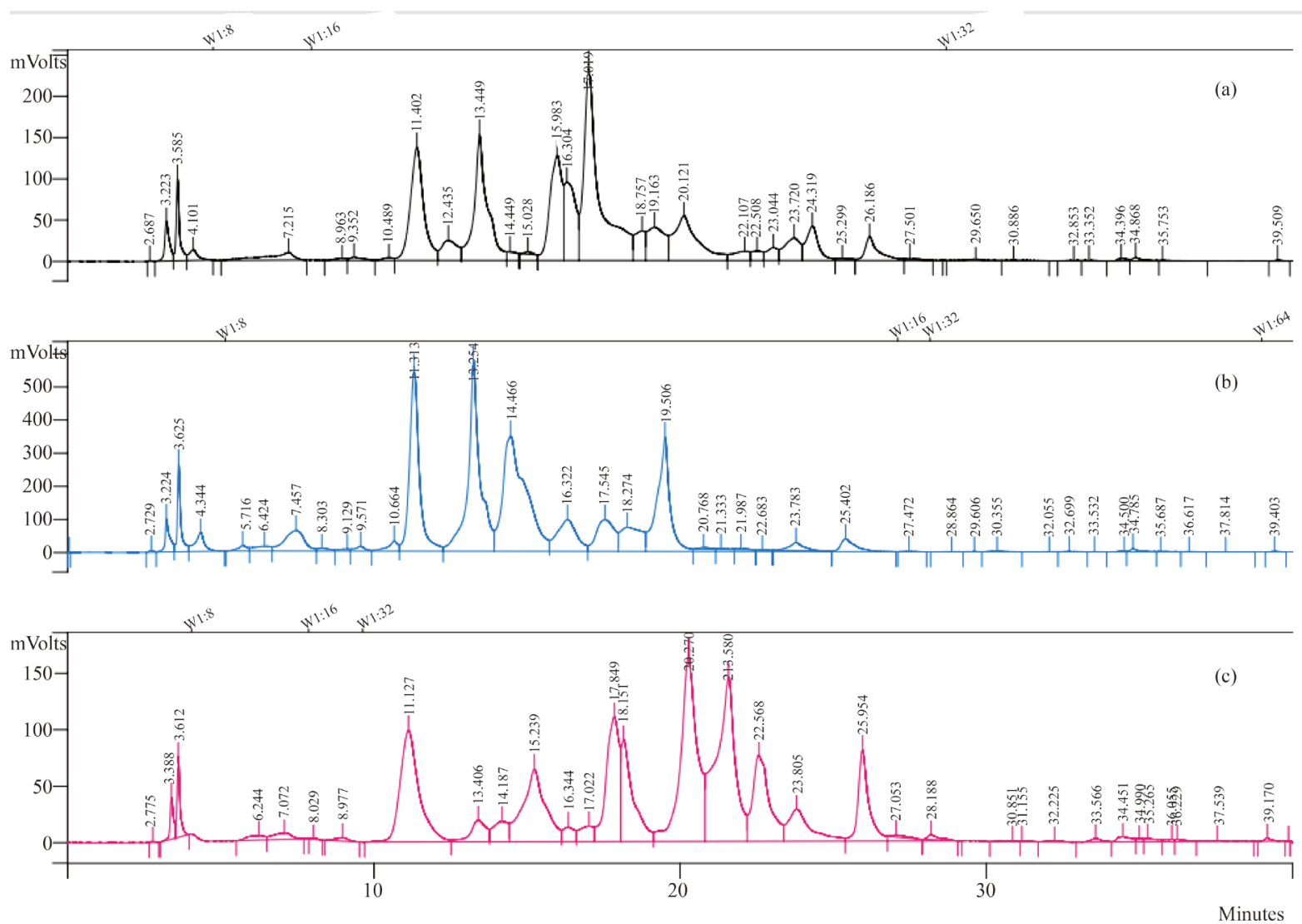

Figure 1. Chromatographic profiles (HPLC/UV, $278 \mathrm{~nm}$ ) of ethanol extracts prepared from the stem bark (a), flowers (b) and leaves (c) of Anacardium occidentale.

Table 1. Antimicrobial activity of ethanol extracts prepared from the stem bark, leaves and flowers of Anacardium occidentale against Gram-positive and Gram-negative bacteria.

\begin{tabular}{ccccc}
\hline Microorganism & \multicolumn{2}{c}{ Crude extract/inhibition halo (mm) $^{*}$} & Chlorhexidine $^{\mathbf{a}}$ \\
\cline { 2 - 3 } & Bark $^{\mathbf{a}}$ & Leaves $^{\mathbf{a}}$ & Flowers $^{\mathbf{a}}$ & \\
Enterococcus faecalis (ATCC 29212) & $13 \pm 3$ & $10 \pm 1$ & $15 \pm 1$ & $20 \pm 1$ \\
Escherichia coli (ATCC 25922) & $10 \pm 1$ & $11 \pm 1$ & $21 \pm 1$ & $20 \pm 1$ \\
Escherichia coli (ATCC 51446) & $\mathrm{NI}^{\mathrm{b}}$ & $10 \pm 1$ & $18 \pm 1$ & $20 \pm 1$ \\
Helicobacter pylori(ATCC 43504) & $11 \pm 1$ & $12 \pm 1$ & $19 \pm 1$ & $24 \pm 1$ \\
Klebsiella pneumoniae (ATCC 700503) & $8 \pm 1$ & $8 \pm 1$ & $13 \pm 3$ & $11 \pm 1$ \\
Klebsiella pneumoniae (ATCC 13883) & $\mathrm{NI}$ & $\mathrm{NI}$ & $12 \pm 1$ & $20 \pm 1$ \\
Lactobacillus acidophilus (ATCC 00076) & $\mathrm{NI}$ & $\mathrm{NI}$ & $15 \pm 1$ & $9 \pm 1$ \\
Proteus mirabilis (ATCC 7002) & $14 \pm 1$ & $12 \pm 1$ & $17 \pm 1$ & $12 \pm 1$ \\
Pseudomonas aeruginosa (ATCC 27853) & $\mathrm{NI}$ & $\mathrm{NI}$ & $19 \pm 1$ & $20 \pm 1$ \\
MRSA (ATCC 3438402) & $16 \pm 1$ & $15 \pm 1$ & $18 \pm 1$ & $20 \pm 1$ \\
Salmonella choleraesuis & $15 \pm 1$ & $14 \pm 2$ & $33 \pm 1$ & $21 \pm 1$ \\
Staphylococcus aureus (ATCC 25923) & $17 \pm 1$ & $16 \pm 1$ & $22 \pm 1$ & $25 \pm 1$ \\
Streptococcus mutans (ATCC 25175) & $\mathrm{NI}$ & $\mathrm{NI}$ & $18 \pm 1$ & $19 \pm 1$ \\
Streptococcus pyogenes(ATCC 19615) & $12 \pm 1$ & $10 \pm 1$ & $16 \pm 1$ &
\end{tabular}

${ }^{\mathrm{a}}$ The results are reported as the mean \pm standard deviation of strains tested in duplicate. ${ }^{\mathrm{b}} \mathrm{NI}$ : no inhibition halo. MRSA: methicillin-resistant Staphylococcus aureus. 
Table 2. Minimum bactericidal concentration of ethanol extracts prepared from the flowers, leaves and stem bark of Anacardium occidentale against Gram-positive and Gram-negative bacteria.

\begin{tabular}{|c|c|c|c|}
\hline \multirow{2}{*}{ Microorganism } & \multicolumn{3}{|c|}{ Crude extract (mg/mL) } \\
\hline & Flowers & Leaves & Bark \\
\hline Escherichia coli (ATCC 25922) & $1.25 \pm 1$ & $20 \pm 1$ & $20 \pm 1$ \\
\hline Escherichia coli (ATCC 51446) & $1.25 \pm 1$ & $10 \pm 1$ & NR \\
\hline Enterococcus faecalis (ATCC 29212) & $10 \pm 1$ & $20 \pm 1$ & $20 \pm 1$ \\
\hline Helicobacter pylori (ATCC 43504) & $5 \pm 1$ & $20 \pm 1$ & $10 \pm 1$ \\
\hline Klebsiella pneumoniae (ATCC 13883) & $20 \pm 1$ & $\mathrm{NP}^{*}$ & NP \\
\hline Klebsiella pneumoniae (ATCC 700503) & $20 \pm 1$ & NP & NP \\
\hline Lactobacillus acidophilus (ATCC 4356) & $5 \pm 1$ & NP & NP \\
\hline Pseudomonas aeruginosa (ATCC 27853) & $1.25 \pm 1$ & NP & NP \\
\hline Proteus mirabilis (ATCC 7002) & $20 \pm 1$ & $20 \pm 1$ & $20 \pm 1$ \\
\hline Staphylococcus aureus (ATCC 25923) & $10 \pm 1$ & $10 \pm 1$ & $20 \pm 1$ \\
\hline MRSA (ATCC 3438402) & $2.5 \pm 1$ & $10 \pm 1$ & $5 \pm 1$ \\
\hline Streptococcus mutans (ATCC 25175) & $2.5 \pm 1$ & NP & NP \\
\hline Streptococcus pyogenes(ATCC 19615) & $5 \pm 1$ & NP & $5 \pm 1$ \\
\hline Salmonella choleraesuis & $0.625 \pm 0$ & $5 \pm 1$ & $5 \pm 1$ \\
\hline
\end{tabular}

"NP: Not performed since no inhibition halo was formed; MRSA: methicillin-resistant Staphylococcus aureus.

Table 3. Antifungal activity of ethanol extracts prepared from the flowers, leaves and stem bark of Anacardium occidentale against Candida sp.

\begin{tabular}{|c|c|c|c|c|c|}
\hline \multicolumn{2}{|c|}{ Species/strain } & \multicolumn{3}{|c|}{ Extract/inhibition halo (mm)* } & \multirow{2}{*}{ Fluconazole } \\
\hline Specı & aln & Flowers $^{\mathrm{a}}$ & Leaves $^{\text {a }}$ & Bark $^{\mathbf{a}}$ & \\
\hline \multirow{4}{*}{ Candida albicans } & ATCC 18804 & $16 \pm 1$ & $\mathrm{NI}^{\mathrm{b}}$ & NI & $15 \pm 1$ \\
\hline & 37 & $19 \pm 1$ & $12 \pm 1$ & $11 \pm 1$ & $13 \pm 1$ \\
\hline & 12 & $17 \pm 1$ & NI & NI & $13 \pm 1$ \\
\hline & 1 & $13 \pm 1$ & NI & NI & $12 \pm 1$ \\
\hline \multirow{4}{*}{ Candida tropicalis } & 39 & $15 \pm 1$ & NI & NI & $15 \pm 1$ \\
\hline & 59 & $14 \pm 1$ & NI & NI & $15 \pm 1$ \\
\hline & 84 & $14 \pm 1$ & NI & NI & $13 \pm 2$ \\
\hline & 82 & $14 \pm 1$ & NI & NI & $14 \pm 0$ \\
\hline
\end{tabular}

${ }^{\mathrm{a}}$ The results are reported as the mean \pm standard deviation of strains tested in duplicate. ${ }^{\mathrm{b}} \mathrm{NI}$ : no inhibition halo. ${ }^{*} \mathrm{p}<0.05$.

Table 4. Minimum fungicidal concentration of ethanol extracts prepared from the flowers, leaves and stem bark of Anacardium occidentale against Candida sp.

\begin{tabular}{|c|c|c|c|c|}
\hline \multirow{2}{*}{\multicolumn{2}{|c|}{ Species /strain }} & \multicolumn{3}{|c|}{ Crude extract(mg/mL) } \\
\hline & & Flowers & Leaves & Bark \\
\hline \multirow{4}{*}{ Candida albicans } & ATCC 18804 & $20 \pm 1$ & $\mathrm{NP}^{*}$ & NP \\
\hline & 37 & $20 \pm 1$ & $>20$ & $>20$ \\
\hline & 12 & $20 \pm 1$ & NP & NP \\
\hline & 1 & $20 \pm 1$ & NP & NP \\
\hline \multirow{4}{*}{ Candida tropicalis } & 39 & $20 \pm 1$ & NP & NP \\
\hline & 59 & $20 \pm 1$ & NP & NP \\
\hline & 84 & $20 \pm 1$ & NP & NP \\
\hline & 82 & $20 \pm 1$ & NP & NP \\
\hline
\end{tabular}

*NP: Not performed since no inhibition halo was formed. 


\subsection{Antioxidant Activity}

Qualitative analysis of the antioxidant activity of EEB, EEL and EEF suggested the presence of compounds with antioxidant activity as indicated by the free radical-scavenging capacity similar a quercetin. The retention factor (Rf) was 0.64 for EEF and EEB and 0.74 for EEL, values similar to that of quercetin (0.85) which was used as the standard. The same was observed for free radical-scavenging capacity, with $\mathrm{EC}_{50}$ values of 0.99 for EEF, 1.47 for EEL, 1.12 for EEB, and 1.71 for quercetin (Table 5). Figure 2 shows the percentage of the DPPH free radical-scavenging activity of the $A$. occidentale extracts and positive control (quercetin) after a reaction time of $30 \mathrm{~min}$. According the results the three extracts showed similar anti-oxidant activity as shown in Figure 2 and detailed in Table 5.

\section{Discussion}

\subsection{Chemical Composition of the Anacardium occidentale Extracts}

Comparison of the chemical composition of EEF, EEL and EEB showed that all extracts are rich in bioactive secondary metabolites, with more strongly positive results observed for the flowers.

Similarly previous results it was possible to identify the presence of saponins, alkaloids, phenolic compounds and tannins in the extracts of A. occidentale [25] [46]-[49]. Differences in the qualitative or semi-quantitative chemical composition of the same plant species may occur between studies because of the influence of factors

Table 5. Antioxidant activity of ethanol extracts prepared from the stem bark, leaves and flowers of Anacardium occidentale compared to quercetin.

\begin{tabular}{ccccccc}
\hline & \multicolumn{5}{c}{ Concentration of the extract $(\boldsymbol{\mu g} / \mathbf{m L})$} & $\mathbf{E C}_{\mathbf{5 0}}$ \\
\cline { 2 - 5 } Sample & $\mathbf{0 . 5}$ & $\mathbf{1}$ & $\mathbf{2}$ & $94 \pm 0.2$ & 0.99 \\
Flowers & $24 \pm 2^{\mathrm{a}}$ & $48 \pm 1$ & $85 \pm 3$ & $90 \pm 0.4$ & 1.47 \\
Leaves & $17 \pm 1$ & $30 \pm 1$ & $57 \pm 1$ & $94 \pm 0.5$ & 1.12 \\
Bark & $22 \pm 2$ & $42 \pm 1$ & $76 \pm 2$ & $94 \pm 0.5$ & 1.71 \\
Quercetin & - & - & - &
\end{tabular}

${ }^{\mathrm{a}}$ The results are reported as the percentage of inhibition of 2,2-diphenyl-1-picrylhydrazyle (DPPH) after a reaction time of 30 min and represent mean \pm SD from quadruplicates.

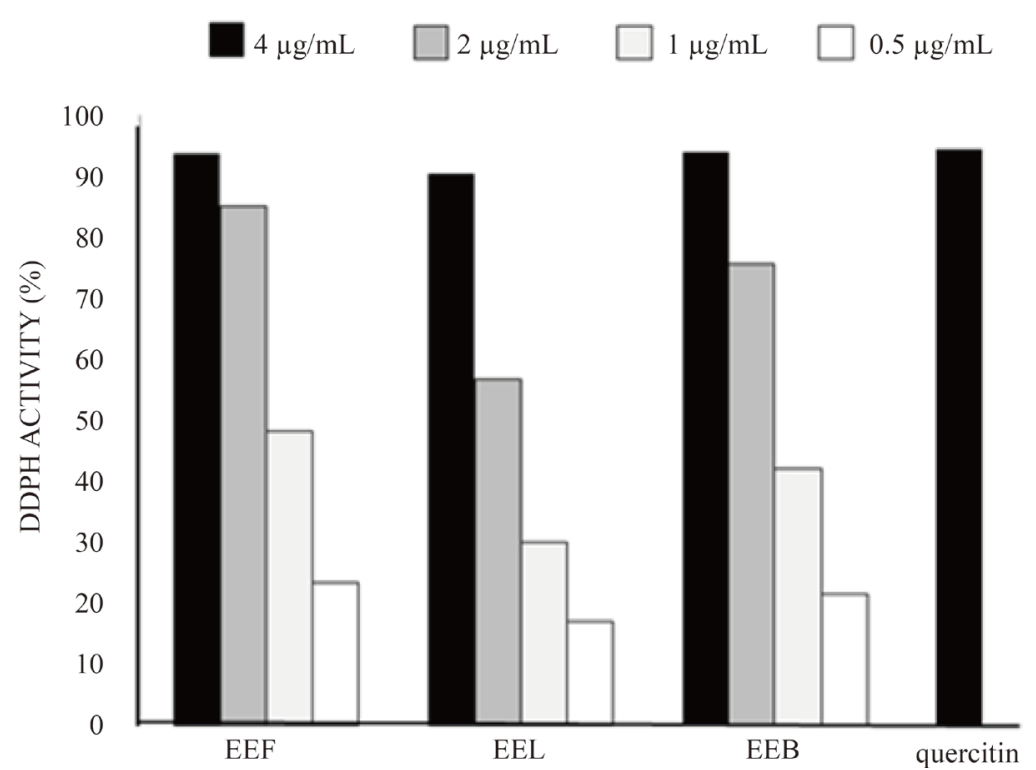

Figure 2. Antioxidant activity of ethanol extracts prepared from the flowers (EEF), leaves (EEL) and stem bark (EEB) of Anacardium occidentale compared to quercetin (Merck; $4 \mu \mathrm{g} / \mathrm{mL}$ ) used as a positive control. Antioxidant activity was evaluated based on DPPH free radical-scavenging activity after $30 \mathrm{~min}$. The results are reported as percent inhibition obtained in quadruplicate for each extract at concentrations of $0.5,1,2$ and $4 \mu \mathrm{g} / \mathrm{mL}$. 
such as plant development, seasonality, circadian rhythm, temperature, rainfall, radiation, nutrients, and altitude, among other environmental factors [34], for this reason We therefore compared extracts collected from different aerial parts during the same period and using the same methods. Although qualitative analysis of the chemical composition showed no significant differences between the extracts, the chromatographic profiles of EEF, EEL and EEB of A. occidentale, obtained under the same conditions of analysis (Figure 1), indicate the presence of different bioactive secondary metabolites in the three extracts, a finding that may explain the higher antimicrobial activity of the extract.

\subsection{Antimicrobial Activity}

Antimicrobial activity against bacteria and fungi, particularly Candida, has been reported for extracts obtained from the fruits, pseudofruits, leaves and bark of A.occidentale [5] [15] [16] [20] [21] [25] [26] [29] [50] [51]. This activity was attributed mainly to the presence of flavonoids, tannins, organic acids, alkaloids, saponins, terpenes, and especially to the presence of phenolic compounds, including anacardic acids, cardol and cardanol [10] [52]-[55]. These compounds have shown antimicrobial activity when tested separately, although their mechanism of action is not fully understood [56] [57].

The antibacterial effect against different bacterial species was observed in the present study for the three extracts of $A$. occidentale (EEF, EEL and EEB). Comparison showed that EEF was more effective than the other extracts (EEL and EEB), inhibiting the growth of all bacteria (Table 1) and fungi (Table 3) tested as indicated by greater inhibition halos, which were often compatible to those formed by the controls (chlorhexidine and fluconazole). Although EEL and EEB also exhibited antimicrobial activity, they were not effective against some bacteria (Escherichia coli, Klebsiella pneumonia, Lactobacillus acidophilus, Pseudomonas aeruginosa, Streptococcus mutans) and against most of the fungi tested (Candida albicans-ATCC 18804; 12; 1; Candida tropicalis-39; 59; 84; 82). These findings indicate the presence of compounds with broad-spectrum antimicrobial activity in EEF. The higher antimicrobial efficacy of EEF was demonstrated by the MBC which ranged from 0.626 $\mathrm{mg} / \mathrm{mL}$ for Salmonella choleraesuis to $20 \mathrm{mg} / \mathrm{mL}$ for Klebsiella pneumonia and Proteus mirabilis. S. choleraesuis was the bacterium most susceptible to EEF considering the inhibition halo (33 mm) and MBC (0.625 $\mathrm{mg} / \mathrm{mL})$.

Antimicrobial resistance has become a leading public health problem in the world. The most common bacteria causing infections, especially nosocomial infections, are S. aureus, MRSA, E. coli and Pseudomonas aeruginosa, all of them resistant to most antibiotics [27] [37] [58]-[63]. The three extracts were effective against S. aureus and MRSA, in agreement with other studies testing the stem bark and leaves of A. occidentale [18] [19] [61], anacardic acid isolated from the cashew nut [10] [63] and CNSL [11].

MRSA are known for their resistance to a series of antibiotics and are therefore frequently associated with infectious complications in hospitalized patients and health professionals [64]. Resistance is mediated by enzymatic inactivation and changes in penicillin-binding proteins. In addition, alterations in membrane permeability prevent the antibiotic from reaching its receptors [65]. In this respect, the effectiveness of the three extracts against these microorganisms is an important finding and indicates the use of the aerial parts of A. occidentale as targets for bioprospection of compounds with antimicrobial activity, especially against MRSA.

Another important finding was the observation that the extracts were effective in inhibiting the growth of extended-spectrum beta-lactamase producers, such as K.pneumoniae (ATCC 700503) and E. coli (ATCC 51446) [66] [67]. The three extracts tested were effective against K. pneumoniae (ATCC 700503), and EEF and EEL were effective against $E$. coli (ATCC 51446). According to Bouttier et al. [68], the antimicrobial activity of $A$. occidentale CNSL is related to the inhibition of beta-lactamase by anacardic acids. Beta-lactamases possess considerable hydrolytic activity and can inactivate a variety of beta-lactam antibiotics [69]. In this respect, anacardic acids emerge as an important alternative for the control of microorganisms that use this strategy as an escape and resistance mechanism to most commercially available antibiotics.

Drug resistance is not only limited to bacteria, but is also observed in pathogenic fungi, particularly Candida albicans which is frequently associated with infections [70]-[72]. Therefore, studies of new antimicrobial agents that are able to overcome multidrug-resistant mechanisms are urgently needed [73]. Within this context, the present results suggest the aerial parts of A. occidentale, especially its flowers, to be promising materials for bioprospection of new broad-spectrum antimicrobial agents that could be used to treat diseases caused by microorganisms which are resistant to commercially available antibiotics. 


\subsection{Antioxidant Activity}

Antioxidants are substances that, when present at low concentrations in relation to the oxidizable substrate, significantly delay or inhibit oxidative processes [45]. In the present study, EEF, EEL and EEB exhibited antioxidant activity compatible to that of quercetin as demonstrated by their ability to scavenge the DPPH free radical. Similar results have been reported for bark [27] [36] and leaf extracts of A. occidentale [74] [75]. Antioxidant activity has been described for compounds isolated from the CNSL, including anacardic acids, cardol and cardanol [34] [38] [76]-[78]. Furthermore, antioxidant activity has been detected in sub-products such as peduncle bagasse [79] [80], cashew apple juice [33], sprouts [81], and cashew nut skin [82]. However, this is the first study reporting antioxidant activity in flowers.

Phenolic compounds are secondary metabolites found in all plants. This group includes simple phenols, hydroxybenzoic acid, derivatives of cinnamic acid, flavonoids, tannins, and coumarins, among others [83]. According to Haslam, natural phenolic compounds have received much attention in recent years due to their capacity to inhibit lipid peroxidation and lipoxygenase in vitro. It is therefore possible that the antioxidant activity observed here is related to the presence of phenolic compounds in the three extracts tested (Table 1).

\section{Conclusion}

The present results show that extracts obtained from the flowers, leaves and stem bark of Anacardium occidentale are rich in bioactive secondary metabolites, exerting a potential antimicrobial effect against Gram-positive and Gram-negative bacteria as well as fungi. The flower extract was the most effective since it inhibited the growth of all microorganisms tested. In addition, the extracts exhibited antioxidant activity compatible to that of quercetin. Taken together, those results suggest an important biotechnological potential of $A$. occidentale as a source of compounds with broad-spectrum antimicrobial activity and of antioxidant compounds to be used in the drug, food and cosmetic industry.

\section{Author's Contribution}

All authors equally contribute to this work

\section{References}

[1] Corrêa, M.P. (1984) Dicionário das plantas úteis do Brasil e das exóticas cultivadas. Instituto Brasileiro de Desenvolvimento Florestal, Rio de Janeiro, 400-402.

[2] Girón, L.M., Freire, V., Alonzo, A. and Cáceres, A. (1994) Ethnobotanical Survey of the Medicinal Flora Used by the Caribs of Guatemala. Journal of Ethnopharmacology, 48, 8-20.

[3] Maia, J.G.S., Andrade, E.H.A. and Zoghbi, M.G.B. (2000) Volatile Constituents of the Leaves, Fruits and Flowers of Cashew (Anacardium occidentale). Journal of Food Composition and Analysis, 13, 227-232. http://dx.doi.org/10.1006/jfca.2000.0894

[4] Assunção, R.B. and Mercadante, A.Z. (2003) Carotenoids and Ascorbic Acid from Cashew Apple (Anacardium occidentale L.): Variety and Geographic Effects. Food Chemistry, 81, 495-502. http://dx.doi.org/10.1016/S0308-8146(02)00477-6

[5] Aguilar,Y.M., Rodríguez, F.S., Saavedra, M.A., Espinosa, R.H. and Yero, O.M. (2012) Metabolitos secundarios y actividad antibacteriana in vitro de extractos de hojas de Anacardium occidentale L. (marañón). Revista Cubana de Plantas Medicinales, 17, 320-329.

[6] Borba, A.M. and Macedo, M. (2006) Plantas medicinais usadas para a saúde bucal pela comunidade do bairro Santa Cruz, Chapada dos Guimarães, MT, Brasil. Acta Botanica Brasilica, 20, 771-782. http://dx.doi.org/10.1590/S0102-33062006000400003

[7] Rodrigues, E. (2007) Plants of Restricted Use Indicated by Three Cultures in Brazil (Caboclo-River Dweller, Indian and Quilombola). Journal of Ethnopharmacology, 11, 295-302. http://dx.doi.org/10.1016/j.jep.2006.11.017

[8] Aiswarya, G., Reza, K.H., Radhika, G. and Farook, S.M. (2011) Study for Antibacterial Activity of Cashew Apple (Anacardium occidentale) Extracts. Der Pharmacia Lettre Journal, 3, 193-200.

[9] Dare, S.S., Hamman, W.O., Musa, S., Goji, A.D.T., Oyewale, A.A., Abba, S. and Ezekiel, I. (2011) Effects of Aqueous Extracts of Anacardium occidentale (Cashew) Leaves on Pregnancy Outcome of Wistar Rats. International Journal of Animal and Veterinary Advances, 3, 77-82. 
[10] Kubo, I., Nihei, K. and Tsujimoto, K. (2003) Antibacterial Action of Anacardic against Methicillin Resistant Staphylococcus aureus (MRSA). Journal of Agricultural and Food Chemistry, 51, 7624-7628. http://dx.doi.org/10.1021/jf034674f

[11] Parasa, L.S., Tumati, S.R., Kumar, L.C.A., Chigurupati, S.P. and Rao, G.S. (2011) In Vitro-Antimicrobial Activity of Cashew (Anacardium occidentale, L.) Nuts Shell Liquid against Methicillin Resistant Staphylococcus aureus (MRSA) Clinical Isolates. International Journal of Pharmacy and Pharmaceutical Sciences, 3, 436-440.

[12] Sujatha, S., Joseph, B. and Antony, E.S. (2011) Analysis of Phytochemical Composition and Bio-Activity against Clinical Pathogens of Essential Oil from Anacardium occidentale (L.). International Journal of Food Safety, 13, 150156.

[13] Kubo, J., Lee, J.R. and Kubo, I. (1999) Anti-Helicobacter pylori Agents from the Cashew Apple. Journal of Agricultural and Food Chemistry, 47, 533-537. http://dx.doi.org/10.1021/jf9808980

[14] Liu, S., Miao, Z., Tang, Y. and Li, C. (2011) Antimicrobial Activity of Cashew (Anacardium occidentale L.) Apple Ethanol Extracts. International Conference on Agricultural and Biosystems Engineering Advances in Biomedical Engineering, Hong Kong, 20 February 2011, 335-337.

[15] Gonçalves, G.M.A. and Gobbo, J. (2012) Antimicrobial Effect of Anacardium occidentale Extract and Cosmetic Formulation Development. Brazilian Archives of Biology and Technology, 55, 843-850. http://dx.doi.org/10.1590/S1516-89132012000600006

[16] Laurens, A., Mboup, S., Giono-Barber, P., Sylla, O. and David-Prince, M. (1982) Étude de l'action antibactérienne d'extraits d'Anacardium occidentale L. Annales Pharmaceutiques Françaises, 40, 143-146.

[17] Mackeen, M.M., Ali, A.M., El-Sharkawy, S.H., Manap, M.Y., Salleh, K.M., Lajis, N.H. and Kawazu, K. (1997) Antimicrobial and Cytotoxic Properties of Some Malaysian Traditional Vegetables (Ulam). Pharmaceutical Biology, 35, 174-178. http://dx.doi.org/10.1076/phbi.35.3.174.13294

[18] Thoha, T.B., Christopher, K., Simeon, J.E. and Sikirat, M. (2012) Antibacterial and Anti-Inflammatory Activities of Anacardium occidentale Leaves and Bark Extracts. Crown Journal of. Medicine, 2, 20-24.

[19] Kudi, A.C., Umoh, J.U., Eduvie, L.O. and Gefu, J. (1999) Screening of Some Nigerian Medicinal Plants for Antibacterial Activity. Journal of Ethnopharmacology, 67, 225-228. http://dx.doi.org/10.1016/S0378-8741(98)00214-1

[20] Akinpelu, D.A (2001) Antimicrobial Activity of Anacardium occidentale Bark. Fitoterapia, 72, 286-287. http://dx.doi.org/10.1016/S0367-326X(00)00310-5

[21] Schmourlo, G., Mendonça-Filho, R.R., Alviano, C.S. and Costa, S.S. (2005) Screening of Antifungal Agents Using Ethanol Precipitation and Bioautography of Medicinal and Food Plants. Journal of Ethnopharmacology, 96, 563-568. http://dx.doi.org/10.1016/j.jep.2004.10.007

[22] Melo, A.F.M., Santos, E.J.V., Souza, L.F.C., Carvalho, A.A.T., Pereira, M.S.V. and Higino, J.S. (2006) In Vitro Antimicrobial Activity of an Extract of Anacardium occidentale L. against Streptococcus Species. Brazilian Journal of Pharmacognosy, 16, 202-205. http://dx.doi.org/10.1590/S0102-695X2006000200012

[23] Mustapha, Y. and Hafsat, S. (2007) Antibacterial Activities of Anacardium occidentale (L.) Leaf Extract against Some Selected Bacterial Isolates. International Journal of Pure and Applied Sciences, 1, 40-43.

[24] Arekemase, M.O., Oyeyiola, G.P. and Aliyu, M.B. (2011) Antibacterial Activity of Anacardium occidentale on Some Enterotoxin Producing Bacteria. International Journal of Biology, 3, 92-99. http://dx.doi.org/10.5539/ijb.v3n4p92

[25] Akinjogunla, O.J., Adenugba, I.T. and Jumbo, O.M. (2012) In-Vitro Antibacterial Evaluation of Ethanolic Stem Crude Extracts of Anacardium occidentale Linn. (Anacardiaceae) on Streptococcus mutans Associated with Dental Caries. Scientific Journal of Microbiology, 1, 71-81.

[26] Braga, F.G., Bouzada, M.L.M., Fabri, R.L., Matos, M.O., Moreira, F.O., Scio, E. and Coimbra, E.S. (2007) Antileishmanial and Antifungal Activity of Plants Used in Traditional Medicine in Brazil. Journal of Ethnopharmacology, 111, 396-402. http://dx.doi.org/10.1016/j.jep.2006.12.006

[27] Santos, E.B., Slusarz, P.A.A., Kozlowski Junior, V.A. and Schwartz, J.P. (2007) Antimicrobial Effectiveness of Natural Products against Microorganisms Related to Bacterial Endocarditis. UEPG Biology-Health Sciences, 13, 67-72.

[28] Jayalakshmi, B., Raveesha, K.A. and Amruthesh, K.N. (2011) Phytochemical Investigations and Antibacterial Activity of Some Medicinal Plants against Pathogenic Bacteria. Journal of Applied Pharmaceutical Science, 1, 124-128.

[29] Saidu, A.N., Akanya, H.O., Dauda, B.E.N. and Ogbadoyi, E.O. (2012) Antibacterial and Comparative Hypoglycemic Effect of Anacardium occidentale Leaves. International Research Journal of Biochemistry and Bioinformatics, 2, 6-10.

[30] Marques, M.R., Albuquerque, L.M.B. and Xavier-Filho, J. (1992) Antimicrobial and Insecticidal Activities of Cashew Tree Gum Exudate. Annals of Applied Biology, 121, 371-377. http://dx.doi.org/10.1111/j.1744-7348.1992.tb03450.x

[31] Torquato, D.S., Ferreira, M.L., Sá, G.C., Brito, E.S., Pinto, G.A.S. and Azevedo E.H.F. (2004) Evaluation of Antimicrobial Activity of Cashew Tree Gum. World Journal of Microbiology and Biotechnology, 20, 505-507. 
http://dx.doi.org/10.1023/B:WIBI.0000040407.90110.c5

[32] Silva, R..A, Guerra, R.N.M. and Monteiro-Neto, V. (2015) Anacardium occidentale: Potencial Antimicrobiano. Novas Edições Acadêmicas, Berlin.

[33] Melo-Cavalcante, A.A., Rubensam, G., Picada, J.N., Silva, E.G., Moreira, F.J.C. and Henriques, J.A.P. (2003) Mutagenicity, Antioxidant Potential and Antimutagenic Activity against Hydrogen Peroxide of Cashew (Anacardium occidentale) Apple Juice and Cajuina. Environmental and Molecular Mutagenesis, 41, 360-369. http://dx.doi.org/10.1002/em.10158

[34] Kubo, I., Masuoka, N., Ha, T.J. and Tsujimoto, K. (2006) Antioxidant Activity of Anacardic Acids. Food Chemistry, 99, 555-562. http://dx.doi.org/10.1016/j.foodchem.2005.08.023

[35] Mokhtar, N.M., Kanthimathi, M.S. and Aziz, A.A. (2008) Comparisons between the Antioxidant Activities of the Extracts of Anacardium occidentale and Piper betle. Malaysian. Journal of Biochemistry and Molecular Biology, 16, 1621.

[36] Chaves, M.H., Citó, A.M.G.L., Lopes, J.A.D., Costa, D.A., Oliveira, C.A.A., Costa, A.F. and Brito Jr., F.E.M. (2010) Total Phenolics, Antioxidant Activity and Chemical Constituents from Extracts of Anacardium occidentale L., Anacardiaceae. Revista Brasileira de Farmacognosia, 20, 106-112. http://dx.doi.org/10.1590/S0102-695X2010000100021

[37] Andrade, D., Leopoldo, V.C. and Haas, V.J. (2006) Ocorrência de bactérias multiresistentes em um centro de Terapia Intensiva de Hospital brasileiro de emergências. Revista Brasileira de Terapia Intensiva, 18, 27-33. http://dx.doi.org/10.1590/s0103-507x2006000100006

[38] Oliveira, M.S.C., Morais, S.M., Magalhães, D.V., Batista, W.P., Vieira, I.G.P., Craveiro, A.A., Menezes, J.E.S.A., Carvalho, A.F.U. and Lima, G.P.G. (2011) Antioxidant, Larvicidal and Antiacetylcholinesterase Activities of Cashew Nut Shell Liquid Constituents. Acta Tropica, 117, 165-170. http://dx.doi.org/10.1016/j.actatropica.2010.08.003

[39] Kubo, I., Komatzu, S. and Ochim, M. (1986) Molluscicides from the Cashew Anacardium occidentale and Their Large-Scale Isolation. Journal of Agricultural and Food Chemistry, 34, 970-973. http://dx.doi.org/10.1021/jf00072a010

[40] Oliveira, F., Akisue, G. and Akisue, M.K. (1991) Farmacognosia. Atheneu, São Paulo, 426 p.

[41] Von Hertwig, I.F. (1991) Plantas aromáticas e medicinais: Plantio, colheita, secagem e comercialização. 2nd Edition, Ícone, São Paulo, 414 p.

[42] McFarland, J. (1907) The Nephelometer: An Estimating the Number of Bacteria in Suspensions for Calculating the Opsonic Index and Vaccines. JAMA, 49, 1176. http://dx.doi.org/10.1001/jama.1907.25320140022001f

[43] Smania Jr, A., Delle Monache, F., Smania, E.F.A. and Cuneo, R.S. (1999) Antibacterial Activity of Steroidal Compounds Isolated from Ganoderma applanatum (Pers.) Pat. (Aphyllophoromycetideae) Fruit Body. International Journal of Molecular Medicine, 1, 325-330. http://dx.doi.org/10.1615/IntJMedMushr.v1.i4.40

[44] Brand-Williams, W., Cuvelier, M.E. and Berset, C. (1995) Use of a Free Radical Method to Evaluate Antioxidant Activity. LWT-Food Science and Technology y, 28, 25-30. http://dx.doi.org/10.1016/S0023-6438(95)80008-5

[45] Sousa, C.M.M., Silva, H.R., Vieira Jr. G. M., Ayres, M.C.C., Costa, C.L.S., Araújo, D.S., Cavalcante, L.C.D., Barros, E.D.S., Araújo, P.B.M., Brandão, M.S. and Chaves, M.H. (2007) Fenóis Totais e Atividade Antioxidante de Cinco Plantas Medicinais. Química Nova, 30, 351-355. http://dx.doi.org/10.1590/S0100-40422007000200021

[46] Mota, M.L.R., Thomas, G. and Barbosa Filho, J.M. (1985) Anti-Inflammatory Actions of Tannins Isolated from the Bark of Anacardium occidentale L. Journal of Ethnopharmacology, 13, 289-300. http://dx.doi.org/10.1016/0378-8741(85)90074-1

[47] Abulude, F.O., Ogunkoya, M.O. and Akinjagunla, Y.S. (2010) Phytochemical Screening of Leaves and Stem of Cashew Tree (Anacardium occidentale). Journal of Agricultural and Food Chemistry, 9, 815-819.

[48] Ojezele, M.O. and Agunbiade, S. (2013) Phytochemical Constituents and Medicinal Properties of Different Extracts of Anacardium occidentale and Psidium guajava. Journal of Pharmaceutical and Biomedical Analysis, 3, 20-23.

[49] Gobbo-Neto, L. and Lopes, N. (2007) Plantas medicinais: Fatores de influência no conteúdo de metabólitos secundários. Química Nova, 30, 374-381. http://dx.doi.org/10.1590/S0100-40422007000200026

[50] Agedah, C.E., Bawo, D.D.S. and Nyananyo, B.L. (2010) Identification of Antimicrobial Properties of Cashew, Anacardium occidentale L. (Family Anacardiaceae). Journal of Applied Sciences and Environmental Management, 14, 2527. http://dx.doi.org/10.4314/jasem.v14i3.61455

[51] Rajashree, R., Robin, G.A.T. and Namashivayam, S.K.R. (2011) First Report of Antimicrobial Activity of Seed Coat Extract from Anacardium occidentale L. (Cashew Nut) on Bacteria and Phytopathogenic Fungi. Journal of Herbs, Spices \& Medicinal Plants, 1, 23-35. http://dx.doi.org/10.1021/jf00002a039

[52] Himejima, M. and Kubo, I. (1991) Antibacterial Agents from the Cashew Anacardium occidentale (Anacardiaceae) nut 
shell oil. Journal of Agricultural and Food Chemistry, 39, 418-421.

[53] Muroi, H. and Kubo, I. (1993) Bactericidal Activity of Anacardic Acids against Streptococcus mutans and Their Potentiation. Journal of Agricultural and Food Chemistry, 41, 1780-1783. http://dx.doi.org/10.1021/jf00034a049

[54] Muroi, H., Kubo, A. and Kubo, I. (1993) Antimicrobial Activity of Cashew Apple Flavor Compounds. Journal of Agricultural and Food Chemistry, 41, 1106-1109. http://dx.doi.org/10.1021/jf00031a018

[55] Kasemura, K., Nomura, M., Tada, T., Fujihara, Y., Shimomura, K. (2002) Antimicrobial and Tyrosinase Inhibitory Activities of 6-[(8Z)-8-Pentadecenyl] Salicylic Acid Derivatives. Journal of Oleo Science, 51, 637-642.

[56] Cowan, M.M. (1999) Plant Products as Antimicrobial Agents. Veterinary Clinical Microbiology, 12, 564-582.

[57] Iwu, M.W., Duncan, A.R. and Okunji, C.O. (1999) New Antimicrobials of Plant Origin. In: Janick, J., Ed., Perspectives on New Crops and New Uses, ASHS Press, Alexandria, 457-462.

[58] Arruda, E.A.G. (1998) Infecção Hospitalar Por Pseudomonas aeruginosa Multi-Resistente: Análise Epidemiológica no HC-FMUSP. Revista da Sociedade Brasileira de Medicina Tropical, 31, 503-504. http://dx.doi.org/10.1590/S0037-86821998000500017

[59] Galoise-Guibal, L., Soubirou, J.L., Desjeux, G., Dusseau, J.Y., Eve, O., Escarment, J. and Ecochard, O. (2006) Screening for Multidrug-Resistant Bacteria as a Predictive Test for Subsequent Onset of Nosocomial Infection. Infection Control \& Hospital Epidemiology, 27, 1233-1241. http://dx.doi.org/10.1086/507277

[60] Lowy, F.D. (1998) Staphylococcus Aureus Infections. The New England Journal of Medicine, 339, 520-532. http://dx.doi.org/10.1056/NEJM199808203390806

[61] Cruvinel, A.R., Silveira, A.R. and Soares, J.S. (2011) Perfil antimicrobiano de staphylococcus aureus isolado de pacientes hospitalizados em UTI no Distrito Federal. Cenarium Pharmacêutico, 4, 1-11.

[62] Silva, J.G., Souza, I.A., Higino, J.S., Siqueira-Júnior, J.P., Pereira, J.V. and Pereira, M.S.V. (2007) Antimicrobial Activity of the Hydroalcoholic Extract of Anacardium occidentale Linn. against Multi-Drug Resistant Strains of Staphylococcus aureus. The Brazilian Journal of Pharmacognosy, 17, 572-577.

[63] Green, I.R., Tocoli, F.E., Lee, S.H., Nihei, K. and Kubo, I. (2007) Molecular Design of Anti-MRSA Agents Based on the Anacardic Acid Scaffold. Bioorganic \& Medicinal Chemistry, 15, 6236-6241. http://dx.doi.org/10.1016/j.bmc.2007.06.022

[64] Chambers, H.F. (1988) Methicillin-Resistant Staphylococci. Clinical Microbiology Reviews, 1, 173-186.

[65] Fuda, C., Suvorov, M., Vakulenko, S.B. and Mobashery, S. (2004) The Basis for Resistance to $\beta$-Lactam Antibiotics by Penicillin-Binding Protein 2a of Methicillin-Resistant Staphylococcus aureus. The Journal of Biological Chemistry, 39, 40802-40806. http://dx.doi.org/10.1074/jbc.M403589200

[66] Rasheed, J.K., Anderson, G.J., Yigit, H., Queenan, A.M., Doménech-Sánchez, A., Swenson, J.M., Biddle, J.W., Ferraro, M.J., Jacoby, G.A. and Tenover, F.C. (2000) Characterization of the Extended-Spectrum $\beta$-Lactamase Reference Strain Klebsiella pneumoniae K6 (ATCC 700603), Which Produces the Novel Enzyme SHV-18. Antimicrobial Agents and Chemotherapy, 44, 2382-2388. http://dx.doi.org/10.1128/AAC.44.9.2382-2388.2000

[67] Haydel, S.E., Remenih, C.M. and Williams, L.B. (2008) Broad-Spectrum in vivo Antibacterial Activities of Clay Minerals against Antibiotic-Susceptible and Antibiotic-Resistance Bacterial Pathogens. Journal of Antimicrobial Chemotherapy, 61, 353-361. http://dx.doi.org/10.1093/jac/dkm468

[68] Bouttier, S., Fourniat, J., Garofalo, C., Gleye, C., Laurens, A. and Hocquemiller, R. (2002) $\beta$-Lactamase Inhibitors from Anacardium occidentale. Pharmaceutical Biology, 40, 231-234. http://dx.doi.org/10.1076/phbi.40.3.231.5827

[69] Jain, A., Roy, I., Gupta, M.K., Kumar, M. and Agarwal, S.K. (2003) Prevalence of Extended Spectrum Beta-Lactamase-Producing Gram-Negative Bacteria in Septicaemic Neonates in a Tertiary Care Hospital. Journal of Medical Microbiology, 52, 421-425. http://dx.doi.org/10.1099/jmm.0.04966-0

[70] Odds, F.C. (1994) Pathogenesis of Candida Infections. Journal of the American Academy of Dermatology, 31, $142-147$. http://dx.doi.org/10.1016/S0190-9622(08)81257-1

[71] Mukherjee, P.K., Chandra, J., Kuhn, D.M. and Ghannoum, M.A. (2003) Mechanism of Fluconazol Resistance in Candida albicans Biofilms: Phase-Specific Role of Efflux Pumps and Membrane Sterols. Infection and Immunity, 71, 4333-4340. http://dx.doi.org/10.1128/IAI.71.8.4333-4340.2003

[72] Cannon, R.D., Lamping, E., Holmes, A.R., Niimi, K., Tanabe, K., Niimi, M. and Monk, B.C. (2007) Candida albicans Drug Resistance Another Way to Cope with Stress. Microbiology, 153, 3211-3217. http://dx.doi.org/10.1099/mic.0.2007/010405-0

[73] Kannan, V.R., Sumathi, C.S., Balasubramanian, V. and Ramesh, N. (2009) Elementary Chemical Profiling and Antifungal Properties of Cashew (Anacardium occidentale L.) Nuts. Bot Research Resources, 2, 253-257.

[74] Jaiswal. Y.S., Tatke, P.A., Gabhe, S.Y. and Vaidya, A. (2010) Antioxidant Activity of Various Extracts of Leaves of 
Anacardium occidentale (Cashew). Research Journal of Pharmaceutical, Biological and Chemical Sciences, 4, 112119.

[75] Arul, V. and Thangavel, K.P. (2011) Antioxidant and Antimicrobial Activity Using Different Extracts of Anacardium occidentale L. International Journal of Applied Biology and Pharmaceutical Technology, 2, 436-443.

[76] Rodrigues, F.H.A., Feitosa, J.P.A., Ricardo, N.M.P.S., França, F.C.F. and Carioca, J.O.B. (2006) Antioxidant Activity of Cashew Nut Shell Liquid (CNSL) Derivatives on the Thermal Oxidation of Synthetic cis-1,4-Polysoprene. Journal of the Brazilian Chemical Society, 17, 265-271. http://dx.doi.org/10.1590/S0103-50532006000200008

[77] Trevisan, M.T.S., Pfundstein, B., Haubner, R., Würtele, G., Spiegelhalder, B., Bartsch, H. and Owen, R.W. (2006) Characterization of Alkyl Phenols in Cashew (Anacardium occidentale) Products and Assay of Their Antioxidant Capacity. Food and Chemical Toxicology, 44, 188-197. http://dx.doi.org/10.1016/j.fct.2005.06.012

[78] Andrade, T.J.A.S., Araújo, B.Q., Citó, A.M., Silva, J., Saffi, J., Richter, M.F. and Ferraz, A.B.F. (2011) Antioxidant Properties and Chemical Composition of Technical Cashew Nut Shell Liquid (CNSL). Food Chemistry, 126, 10441048. http://dx.doi.org/10.1016/j.foodchem.2010.11.122

[79] Broinizi, P.R.B., Andrade-Wartha, E.R.S., Silva, A.M.O., Novoa, A.J.V., Torres, R.P., Azeredo, H.M.C., Alves, R.E. and Mancini-Filho, J. (2007) Avaliação da Atividade Antioxidante dos Compostos Fenólicos Naturalmente Presentes em Subprodutos do Pseudofruto de Caju (Anacardium occidentale L.). Ciencia e Tecnologia de Alimentos, 27, 902-908. http://dx.doi.org/10.1590/S0101-20612007000400035

[80] Broinizi, P.R.B., Andrade-Wartha, E.R.S., Silva, A.M.O., Torres, R.P., Azeredo, H.M.C., Alves, R. and Mancini-Filho, J. (2008) Propriedades antioxidantes em subproduto do pedúnculo de caju (Anacardium occidentale L.): Efeito sobre a lipoperoxidação e o perfil de ácidos graxos poliinsaturados em ratos. Revista Brasileira de Ciências Farmacêuticas, 44, 773-781. http://dx.doi.org/10.1590/S1516-93322008000400025

[81] Kamath, V. and Rajini, P.S. (2007) The Efficacy of Cashew Nut (Anacardium occidentale L.) Skin Extract as a Free Radical Scavenger. Food Chemistry, 103, 428-433. http://dx.doi.org/10.1590/S1516-93322008000400025

[82] Naczk, M. and Shahidi, F. (2004) Extraction and Analysis of Phenolics in Food. Journal of Chromatography, 1054, 95-111. http://dx.doi.org/10.1016/S0021-9673(04)01409-8

[83] Haslam, E. (1996) Natural Polyphenols(Vegetable Tannins) as Drugs: Possible Modes of Action. Journal of Natural Products, 59, 205-215. http://dx.doi.org/10.1021/np960040+ 